\title{
An analytical technique for simultaneously estimating crystallization age and temperature of zircon using LA-ICP-MS
}

\author{
*T. YOKOYAMA ${ }^{1}$, T. YUGUCHI ${ }^{2}, \mathrm{~S}_{\text {. SAKATA }}^{3}$, \\ K. ISHIBASHI ${ }^{2}$, Y. OGITA ${ }^{1}$, D. ITO ${ }^{2}$, T. OHNO ${ }^{4}$, \\ S. KAGAMI ${ }^{1}$, T. MitSUGUCHI ${ }^{1}$ AND S. SUEOKA ${ }^{1}$ \\ ${ }^{1}$ Japan Atomic Energy Agency, Gifu, Japan \\ (*correspondance: yokoyama.tatsunori@jaea.go.jp) \\ ${ }^{2}$ Yamagata University, Yamagata, Japan \\ ${ }^{3}$ The University of Tokyo, Tokyo, Japan \\ ${ }^{4}$ Gakushuin University, Tokyo, Japan
}

Dating and trace elements analysis of zircons provide us the evidences of past thermal history about their growth events, such as timing and temperature of magmatism and crystallization. In granitic rocks, because the proposed closure temperature of zircon $\mathrm{U}-\mathrm{Pb}\left(>900{ }^{\circ} \mathrm{C}\right)$ is often higher than crystallization temperature of the zircon [1], the zircon $\mathrm{U}-\mathrm{Pb}$ age means the timing of crystallization. To clarify the growth history of granitic pluton, Yuguchi et al. (2016) [2] performed the observation of internal structure of zircon (collected from the Toki granite, central Japan) using cathodoluminescence, deriving crystallization temperature and age using Ti-in-zircon thermometry $[3]$ and $\mathrm{U}-\mathrm{Pb}$ dating. It is important to discuss the emplacement by such an approach to understand the history of upheaval and exhumation of igneous complex.

In this study, for simultaneously estimating crystallization age and temperature of zircon, we performed $\mathrm{U}-\mathrm{Pb}$ isotopic analysis and quantitative analysis of Titanium, in the same position of zircon, using LA-ICP-MS after the cathodoluminescence observation. As preliminary experiments, we analyzed zircons collected from Japan (e.g., Okue, Tono, Toki and Kurobegawa granites) to estimate their thermal history. We could estimate the crystallization ages and temperatures of zircons of Okue $\left(556-946^{\circ} \mathrm{C}\right.$ in $11.1-$ 16.1 Ma), Tono $\left(613-901^{\circ} \mathrm{C}\right.$ in $\left.110.2-127.4 \mathrm{Ma}\right)$, Toki (575$734^{\circ} \mathrm{C}$ in $\left.69.4-79.9 \mathrm{Ma}\right)$ and Kurobegawa $\left(636-779^{\circ} \mathrm{C}\right.$ in $0.46-1.85 \mathrm{Ma})$, respectively.

This study was carried out under a contract with METI as part of its $R \& D$ supporting program for developing geological disposal technology.

[1] Fu et al. (2008) Contrib. Mineral. Petrol. 156, 197-215.

[2] Yuguchi et al. (2016) J. Mineral. Petrol. Sci. 111, 9-34.

[3] Watson et al. (2006) Contrib. Mineral. Petrol. 151, 413433. 